East African Medical Journal Vol. 81 No. 4 April 2004

COMPARISON OF VAGINAL AND ORAL MISOPROSTOL, FOR THE INDUCTION OF LABOUR IN WOMEN WITH INTRA-UTERINE FOETAL DEATH

L. Nyende, MBChB., MMed (SA) O. A. Towobola, PHD., M.H. Mabina, MBChB, FCOG. (SA)., Department of Obstetrics and Gynaecology, Medical University

of Southern Africa (MEDUNSA), South Africa

Request for reprints to: Prof. O. A. Towobola, Department of Obstetrics and Gynaecology, Medical University of Southern Africa (MEDUNSA), P.O Box 149,Medunsa, 0204, Pretoria, South Africa

\title{
COMPARISON OF VAGINAL AND ORAL MISOPROSTOL, FOR THE INDUCTION OF LABOUR IN WOMEN WITH INTRA-UTERINE FOETAL DEATH
}

\author{
L. NYENDE, O. A. TOWOBOLA and M.H. MABINA
}

\begin{abstract}
Objective: To compare the efficacy of vaginal and oral misoprostol for the induction of labour in women with intra-uterine foetal death (IUFD).

Design: A prospective randomised clinical trial, comparing $200 \mu \mathrm{g}$ oral and $200 \mu \mathrm{g}$ vaginal misoprostol, six hourly for a maximum of four doses for the induction of labour in women with IUFD.

Setting: Ga-Rankuwa hospital (Department of Obstetrics and Gynaecology), Pretoria, South Africa. It is a tertiary institution serving predominantly black indigenous population.

Main outcome measures: The primary outcome measure was the induction to delivery time, and secondary outcome measures were the number of patients requiring augmentation with oxytocin and all complications were noted.

Results: Twenty women were randomised to the vaginal route and 18 to the oral route. The induction to delivery time was shorter with vaginal misoprostol $(13.5 \pm 8.3 \mathrm{hrs})$ compared to oral misoprostol $(21.4 \pm 13.9 \mathrm{hrs} ; \mathrm{p}<\mathrm{0.05})$. There was no significant difference in the amount of misoprostol needed to achieve successful induction in the two groups. More women (10/18) who received oral misoprostol required oxytocin augmentation to complete the induction of labour compared with 4/20 women in the vaginal group ( $p<0.05$; Odds Ratio 2.8 ; $95 \%$ Cl 1.36 - 4.24). There were no cases of failed induction. The systemic side effects (shivering, diarrhoea, vomiting and pyrexia) were more common with oral misoprostol $(44.5 \%)$ compared to vaginal misoprostol $(20 \%)$. This difference gives an overall Odds Ratio of 2.2 at $95 \% \mathrm{Cl}$ of $1.6-2.8(\mathbf{p}<0.05)$. Conclusion: Vaginal misoprostol achieved successful induction of labour in women with IUFD in a shorter time than oral misoprostol with significantly less side effects.
\end{abstract}

\section{INTRODUCTION}

Misoprostol (Cytotec, Searle) is a prostaglandin $\mathrm{E}_{1}$ analogue, a methyl-ester of prostaglandin $\mathrm{E}_{1}$ additionally methylated at C-16. It is registered in Republic of South Africa (RSA), for prophylaxis and treatment of peptic ulcer disease caused by non-steroidal anti- inflammatory drugs (prostaglandin inhibitors). In addition, misoprostol is an effective myometrial stimulant of pregnant uterus, selectively binding to EP-2/EP-3 prostanoid receptors(1). Mariani-Neto et al.(2) first reported using oral misoprostol (400 $\mu \mathrm{g}$ four hourly), for the induction of labour following IUFD. All the 20 patients delivered. However, along with its effectiveness, the authors described cases of excessive uterine activity with its use at term. Many subsequent studies have shown that misoprostol is effective, easy to use and a cheap drug for induction of labour(3-5), in women with IUFD. However, the preferred route of administration of misoprostol is still uncertain. Three trials compared oral and vaginal misoprostol using different doses(6-8), and their results were inconsistent.

Misoprostol is rapidly absorbed orally and vaginally(9). Zieman et al.(9) in a randomised comparison of absorption kinetics of $400 \mu \mathrm{g}$ of oral and vaginal misoprostol showed that the plasma concentration of misoprostol after oral administration, rose quickly, reaching a peak $(227 \mathrm{pg} / \mathrm{ml}) 34$ minutes after administration, fell steeply by 120 minutes and remained low for the duration of the study. In contrast, plasma concentration of misoprostol acid in subjects who received vaginal misoprostol rose gradually reaching a peak $(165 \mathrm{pg} / \mathrm{ml})$ at approximately 80 minutes after administration and declined slowly, to an average of $61 \%$ of the peak level at 240 minutes after administration. The objective of this study was to compare the efficacy of oral versus vaginal misoprostol for the induction of labour in women with IUFD after 20 weeks of gestation. 


\section{MATERIALS AND METHODS}

Thirty eight pregnant women with IUFD were asked to participate in a randomised clinical trial where the vaginal and oral routes of administration of misoprostol were compared. The study was conducted at Ga-Rankuwa hospital, MEDUNSA, which serves a mainly black indigenous population. Prior to entry to the trial, confirmation of IUFD was made by ultra sound examination. Written informed consent was obtained from each woman before randomisation. Only women with a confirmed IUFD, singleton pregnancy, cephalic presentation and parity less than five were asked to participate. Women with a malpresentation, foetal macrosomia, previous uterine scar, any contra indications to receiving prostaglandin and renal or hepatic dysfunction were specifically excluded.

Randomisation was performed using sealed opaque envelopes containing a piece of paper indicating the route of administration. These envelopes were placed in a box from which the women picked one at random. The researcher did not participate in the packing of the envelopes. All patients participating in the study were admitted in antenatal ward. The initial assessment included patients' demographic features: (age, parity, gestational age), duration of IUFD and an initial Bishop score. The gestational age was calculated from the last normal menstrual period and the duration of IUFD from the date of last foetal movement perception.

Misoprostol 200 micro grams was administered six hourly orally or vaginally (in the posterior fornix), for a maximum of four doses, or until labour was established. Patients who progressed to active labour were transferred to labour ward and managed accordingly. Oxytocin augmentation was commenced six hours after the last dose of misoprostol if the patient was not yet in established labour, using an established standard oxytocin regime of 2 units, 8 units, 16 units in one litre 5\% dextrose at 15 drops, 30 drops and 60 drops per minute respectively (i.e. $2 \mathrm{mU}, 4 \mathrm{mU}, 8 \mathrm{mU}, 16$ $\mathrm{mU}, 32 \mathrm{mU}$ and $64 \mathrm{mU}$ per minute respectively), increments at half hourly intervals.

The primary outcome measure was the induction to delivery time, and secondary outcome measures were the number of patients requiring augmentation with oxytocin and all complications were noted. If the woman was not in established labour six hours after commencement of oxytocin, the induction was deemed a failure.

Standard statistical methods (p-value; Odds Ratio and 95\% Confidence Interval) were used to analyse the data. The study was conducted, following approval by the MEDUNSA Ethics Committee and the Chief Superintendent of the hospital.

\section{RESULTS}

Thirty eight women were randomised for the study, of whom 18 received oral misoprostol and 20 vaginal misoprostol. Both groups were comparable with respect to maternal age, parity, gestational age at the time of foetal demise, duration of the intra-uterine death, and Bishop score at commencement of induction (Table 1). There were no cases in which labour could not be induced. There were no post randomisation exclusions, and no woman withdrew from the trial after consent had been given.

Table 1

Comparison of women with IUFD undergoing induction of labour with misoprostol

\begin{tabular}{llll}
\hline & $\begin{array}{l}\text { Vaginal } \\
\text { administration }\end{array}$ & $\begin{array}{l}\text { Oral } \\
\text { administration }\end{array}$ & P-value \\
\hline $\begin{array}{l}\text { Maternal age } \\
\text { (mean } \pm \text { SD) }\end{array}$ & $26.3 \pm 4.9$ & $24.7 \pm 5.6$ & NS \\
$\begin{array}{l}\text { Parity } P_{\text {o }} \\
P_{1-2}\end{array}$ & 10 & 8 & NS \\
$\quad P_{3-4}$ & 6 & 8 & NS \\
$\begin{array}{l}\text { Gestational age } \\
\text { (mean } \pm \text { SD; weeks) }\end{array}$ & $27.4 \pm 5.0$ & $29.2 \pm 4.5$ & \\
$\begin{array}{l}\text { Duration of IUFD } \\
\text { (mean } \pm \text { SD; weeks) }\end{array}$ & $1.7 \pm 0.8$ & $1.8 \pm 0.8$ & \\
Initial Bishop's score & & & \\
$\quad<$ & 2 & 1 & \\
$\quad 4-6$ & 15 & 2 & \\
$\quad>6$ & 3 & & \\
\hline
\end{tabular}


Table 2

Comparison of the effect of induction of labour with vaginal and oral route of administration of misoprostol

\begin{tabular}{|c|c|c|c|}
\hline & Vaginal & Oral & P-value \\
\hline Induction to $($ mean $\pm \mathrm{sd})$ & $13.5 \pm 8.3$ & $21.4 \pm 13.9$ & $<0.05$ \\
\hline Delivery time (median) & 11.9 & 18.3 & \\
\hline (range) & $3.6-32.7$ & $4.0-47.9$ & \\
\hline Oxytocin augmentation & $4 / 20(20 \%)$ & $10 / 18(55.6 \%)$ & $<0.05$ \\
\hline $\begin{array}{l}\text { Dose of misoprostol } \\
\text { used }(\mu \mathrm{g})(\text { mean } \pm \mathrm{sd})\end{array}$ & $420.0 \pm 233.1$ & $537.5 \pm 249.7$ & NS \\
\hline
\end{tabular}

Table 3

A comparison of side effects of vaginal and oral administration of misoprostol for the induction of labour

\begin{tabular}{llll}
\hline & Vaginal & Oral & P-value \\
\hline Vomiting & $2 / 20(10 \%)$ & $3 / 18(16.7 \%)$ & $1.7(0.0-3.6)$ \\
Diarrhoea & $1 / 20(5 \%)$ & - & $3.3(0.95-5.65)$ \\
Shivering & $1 / 20(5 \%)$ & $2 / 18(11.1 \%)$ & \\
Pyrexia & - & - & $\mathrm{p}<0.05$ \\
Hyperstimulation & - & $44.5 \%$ & \\
Uterine rupture & - & & \\
\hline Total rate of side effects & $20 \%$ & & \\
\hline
\end{tabular}

The mean induction to delivery time was $21.4 \pm$ 13.9 hours in the oral group and $13.5 \pm 8.3$ hours in the vaginal $(\mathrm{p}<0.05$; Table 2$)$. A higher mean dose of misoprostol was required for successful induction in the oral group $(537.5 \pm 249 \mu \mathrm{g})$ than in the vaginal group $(420 \pm 233 \mu \mathrm{g})$ but this difference was not statistically significant. In addition, more women in the oral group required oxytocin augmentation $10(55 \%)$ patients than in the vaginal group four $(20 \%)$ patients (p< 0.05; Odds Ratio 2.8; 95\% Cl 1.36-4.24;) (Table 2.)

There were no major complications but only minor systemic side effects namely: vomiting, diarrhoea, shivering and pyrexia, these were more common in the oral group $(44.5 \%)$ than in the vaginal group (20\%), (p>0.05; Odds Ratio 2.2; 95\% Cl 1.6 - 2.8; Table 3. There were no cases of uterine rupture.

\section{DISCUSSION}

In this study, the mean induction to delivery time was significantly shorter in the vaginal group (13.5 \pm 8.3 hours) when compared to the oral group (21.4 \pm 13.9 hours). Furthermore significantly more women in the oral group required oxytocin augmentation 10 $(55.6 \%)$ of 18 patients than in the vaginal group four $(20 \%)$ of 20 patients $(\mathrm{p}<0.05)$. The doses of misoprostol used in this present trial were higher $(200 \mu \mathrm{g}$ six hourly) than in other trials $(6,8)$.

Topozada et al.(6) compared vaginal versus oral misoprostol for induction of labour in 40 women who were randomised into two equal groups. Group I received vaginal misoprostol $(100 \mu \mathrm{g})$ every three hours while group II patients were given the same dose via the oral route. The vaginal route of administration induced a higher success rate in a shorter time interval using a lower dose, but was associated with more abnormal foetal heart rate pattern and instances of uterine hyper-stimulation. The authors recommended the use of the vaginal approach with cardio-tocographic monitoring.

Wing et al.(7) in a randomised clinical trial comparing $50 \mu \mathrm{g}$ misoprostol administered orally and $25 \mu \mathrm{g}$ misoprostol intra-vaginally, 220 subjects were randomised, 110 in each arm of the study. Significantly fewer subjects who received the oral preparation (30.9\%) were delivered vaginally within 24 hours of initiation of induction, in comparison with those who received the vaginal preparation $(47.3 \%)$. The average interval from start of induction to vaginal delivery was nearly six hours longer in the oral treatment group (mean and SD 1737.9 \pm 845.7 minutes) than in the vaginal treatment group (mean and SD $1393.2 \pm$ 767.9) ( $\mathrm{p}=0.005$ ). Orally treated patients required significantly more doses than vaginally treated patients (orally administered doses; mean and $\mathrm{SD}=3.3 \pm 1.7$; vaginally administered doses: mean and $\mathrm{SD}=2.3 \pm$ 1.2) with a p-value $<0.0001$. Furthermore oxytocin administration was necessary in 83 of $110(75.4 \%)$ orally treated subjects and in 65 of $110(59.1 \%)$ vaginally treated subjects $(\mathrm{p}=0.01)$. These authors concluded that oral administration of $50 \mu \mathrm{g}$ doses of 
misoprostol appears less effective than vaginal administration of $25 \mu \mathrm{g}$ doses of misoprostol for cervical ripening and labour induction.

They recommended further investigation to determine whether orally administered misoprostol should be used for cervical ripening and labour induction. Adair et al.(8) on the other hand did not find any significant difference in the efficacy in a randomised double blind trial comparing 50 $\mathrm{\mu g}$ of vaginal misoprostol and $200 \mu \mathrm{g}$ of oral misoprostol for labour induction. The most important side effects of misoprostol are nausea, vomiting and dose dependent diarrhoea, stomach-ache and flatulence(10).

In this trial significantly more side effects were reported in the oral misoprostol group with, in order of frequency; vomiting, shivering and pyrexia being the most common. Hofmeyr, et al.(11) in a randomised placebo controlled trial of oral misoprostol in the third stage of labour, using oral misoprostol $400 \mu \mathrm{g}$, found that shivering was more common in the misoprostol group (19\% vs 5\%, relative risk 3.69; $95 \%$ confidence interval $2.05-6.64)$. They concluded that shivering was a specific side effect of misoprostol administered orally in the puerperium. Lumbiganon, et al.(12) reported misoprostol dose-related shivering and pyrexia in the third stage of labour. Comparing misoprostol $400 \mu \mathrm{g}$ versus misoprostol $600 \mu \mathrm{g}$ both shivering and pyrexia (temperature $>38^{\circ} \mathrm{C}$ ) were more common in the $600 \mu \mathrm{g}$ misoprostol group $(28 \%$ and $7.5 \%$ for shivering and pyrexia, respectively) compared with $400 \mu \mathrm{g}$ misoprostol (19\% and 2\%).

There was no case of uterine rupture in this study. However, this study did not aim to test the safety of the different routes of administration of misoprostol. Misoprostol causes potent uterine contractions and these can lead to hyper-stimulation of the uterus and eventually to uterine rupture. The effect of uterine hyper-stimulation is most important when misoprostol is used to induce labour where there is a live foetus. In the case of IUFD, uterine rupture is still of concern. However, the number of women required to test the comparative safety of the two routes of administration would be too large for one institution to answer.

\section{ACKNOWLEDGEMENTS}

To Prof. R. C. Pattinson of Pretoria University for his assistance in the preparation of this manuscript as well as all my colleagues and the Nursing Staff; Department of Obstetrics and Gynaecology, for their cooperation.

\section{REFERENCES}

1. Senior J., Marshall, K., Sangha, R., and Clayton, J.K. In vitro characterisation of prostanoid receptors on human myometrium at term pregnancy. Brit. J. Pharm. 1993; 108:501-506.

2. Mariani-Net, C., Leao, E.J., Baretto, E.M., Kenj, G., and De Aquino, M.M. Use of misoprostol for labour induction in stillbirth. Rev. Paul. Med. 1987; 105:325-328.

3. Bugalho, A. Bique, C, Machungo, F., and Bergstrom, S. Vaginal misoprostol as an alternative to oxytocin for induction of labour in women with late foetal death. Acta. Obstet. Gynecol. Scand. 1995; 74:194-198.

4. Sanchez-Ramos, L., Kaunitz, A.M., Wears, R.L., Delke, I. and Gaudier, F.L. Misoprostol for cervical ripening and labor induction: (a meta-analysis) Obstet. Gynecol. 1997; 89: 633-642.

5. Hofmeyer, G.J. Vaginal misoprostol for cervical ripening and labour induction in late pregnancy. The Cochrane Library 1999; 2:1-18. (Meta-Analysis).

6. Toppozada, M.K., Anwar, M.Y.M., Hassan, H.A. and ElGazaerly, W.S. Oral or vaginal misoprostol for induction of labour. Int J. Gynecol. Obstet. 1997; 56:135-139.

7. Wing, D.A., Ham, D. and Paul, R.H. A comparison of orally administered misoprostol with vaginal misoprostol for cervical ripening and labour induction. Amer. J. Obstet. Gynecol. 1999; 180:1155-1160.

8. Adair, C.D. Weeks, J.W., Barrileaux, P.S., Philibert, L., Edwards, M.S., and Lewis, D.F. Labour induction with oral versus vaginal misoprostol: A randomised double-blind trial. Amer. J. Obstet. Gynecol. 1998; 178:5111.

9. Zieman, M., Fong, S.K., Benowitz, N.L., Banskter, D., and Damey, P.D. Absorption kinetics of misoprotol with oral or vaginal administration. Obstet. Gynecol. 1997; 90:88-92.

10. Scheepers, H.C.J., Van Erp, E.J.M. and Van den, Bergh, A.S. Use of misoprostol in first and second trimester abortion. A review. Obstet. Gynecol. survey. 1999; 54: 592-600.

11. Hofmeyr, G.T., Nikodem, V.C., Mirinda de Jager, and Gelhart, B.R. A randomised placebo controlled trial of oral misoprostol in the third stage of labour. Brit. J. Obstet. Gynaecol. 1998; 105:971-975.

12. Lumbiganon, P., Hofmeyr, G.J., Gulmezoglu, A.M., Pinol, A. and Villar, J. Misoprostol dose related shivering and pyrexia in the third stage of labour. Brit. J. Obstet. Gynaecol. 1999; 106:304-308. 